\title{
Comparative metabolic state of microflora on the surface of the anode electrode in a microbial fuel cell operated at different $\mathrm{pH}$ conditions
}

\author{
Daisuke Sasaki ${ }^{1}$, Kengo Sasaki ${ }^{1}$, Yota Tsuge ${ }^{2}$ and Akihiko Kondo ${ }^{1,3,4^{*}}$
}

\begin{abstract}
The metabolic state of microflora (mixed microbial cultures) in microbial fuel cells (MFCs) is currently unclear. Metabolomic analyses were conducted of microflora growing on the anodic electrodes of MFCs operated at pH 7.0, 5.5, or 4.0 and utilizing starch as the major carbon substrate. A much higher current was produced at $\mathrm{pH} 7.0$ than at $\mathrm{pH} 5.5$ and 4.0, correlating with an increased population ratio of Geobacter species to the total bacteria growing on the electrode. Most intracellular metabolites related to the tricarboxylic acid (TCA) cycle were present at a higher level at pH 7.0 than at pH 5.5 and 4.0, and the levels of metabolites correlated well with the obtained current densities. A high intracellular adenosine triphosphate (ATP)/adenosine diphosphate (ADP) ratio at pH 7.0, compared to at pH 5.5 and 4.0, likewise supported current production. Overall, the metabolomic analyses demonstrated that activation of the TCA cycle and increased ATP generation are critical parameters for electricity generation by microflora.
\end{abstract}

Keywords: Microbial fuel cell, Microflora, Intracellular metabolomic analysis, TCA cycle, ATP generation

\section{Introduction}

Microbial fuel cells (MFCs) are being investigated for the simultaneous treatment of organic and inorganic materials such as wastewater and for generating electricity by using mixed cultures of microflora as the catalyst (Logan et al. 2006; Lovley 2008). Electrons generated by oxidation of the reduced substrate at the anode flow to the cathode through the circuit, resulting in the reduction of oxygen (Logan 2009). In most cases, MFCs employ microflora rather than a pure culture because mixed cultures can utilize complex organic materials as substrates and enhance anodophilic electron transfer due to interspecies connections (Logan et al. 2006). The effects of system architecture and operational parameters on electricity generation in MFCs have been intensively studied (Logan et al. 2006). Air-cathode MFCs, in which

${ }^{*}$ Correspondence: akondo@kobe-u.ac.jp

${ }^{1}$ Graduate School of Science, Technology and Innovation, Kobe University, 1-1 Rokkodaicho, Nada-ku, Kobe, Hyogo 657-8501, Japan Full list of author information is available at the end of the article the cathode is in direct contact with the air, are useful because there is no need for aeration or chemical catholytes, there is high electrical output, and they are suitable for scale-up (Shimoyama et al. 2008). Electricity generation can be modulated by $\mathrm{pH}$, which is one important parameter ( $\mathrm{He}$ et al. 2008); however, although the $\mathrm{pH}$ range for adequate current generation is relatively broad (between $\mathrm{pH} 7$ and 10), $\mathrm{pH}$ conditions close to neutral are usually used in MFCs to support the growth of anodic bacteria in air-cathode systems (He et al. 2008). To date, the conditions supporting efficient bacterial growth and current generation have been investigated, but less effort has been devoted to investigating the intracellular metabolic states of anode-respiring microflora in air-cathode MFCs.

Geobacter sulfurreducens is the primary microorganism used for current production and its electron transfer mechanism has been well studied (Lovley 2012). Recent advances in metabolomic analysis allow clarification of the intracellular metabolic states of microorganisms (Toya and Shimizu 2013) and this approach has shown 
that pure cultures of G. sulfurreducens activate the tricarboxylic acid (TCA) cycle and down-regulate gluconeogenesis under conditions compatible with electricity generation (Song et al. 2016). Metabolomic analysis can also be applied to microflora to understand the metabolic state of a bacterial community as a whole. In microflora used for methane fermentation, the Embden-Meyerhof (EM) pathway is inhibited and simultaneously the reductive branch of the TCA cycle is stimulated when the $\mathrm{pH}$ is decreased from 7.5 to 5.0, and methane fermentation is inhibited (Sasaki et al. 2014). This finding suggests that metabolomic analysis would be useful for evaluating the conditions for optimizing the performance of microflora in MFCs.

The aim of this study was to clarify the metabolic state of microflora on the surface of the anodic electrode in an air-cathode MFC operated at $\mathrm{pH} 7.0$ to generate current. The metabolic states of microflora in comparable MFCs operated at $\mathrm{pH} 5.5$ or 4.0 and producing a relatively low current were used as controls. Starch was the major carbon source in the substrate, simulating wastewater containing carbohydrate.

\section{Materials and methods MFC configuration}

The MFC reactor had one cassette-electrode comprising an air cathode, a separator, and an anode, and this construction was mirrored on the other side of the air inlet interspace. This reactor represents a minor modification of a previously described reactor (Miyahara et al. 2013) (Fig. 1). Carbon paper (TGP-H-120; MICLAB, Kanagawa, Japan) coated with four 4-polytetrafluoroethylene (PTFE) layers and $1 \mathrm{mg} \mathrm{cm}^{-2}$ of a cathode catalyst [Pt-carbon (TEC10E70TPM); Tanaka Kikinzoku Kogyo, Tokyo, Japan] was used as the air cathode, and graphite felt (F-203G; Sohgoh Carbon, Yokohama, Japan) and a glass filter (GF/A; GE Healthcare, Little Chalfont, UK) were utilized for the anode and separator, respectively. The reactor had a total anode or cathode area of $144 \mathrm{~cm}^{2}$ in the one cassette-electrode and a total volume of $250 \mathrm{~mL}$ fermentation broth.

\section{Operation of the MFC}

The MFC reactor was filled with synthetic wastewater (Guerrero et al. 2009) adjusted to $\mathrm{pH} 7.0,5.5$, or $\mathrm{pH} 4.0$ using $20 \mathrm{mM}$ phosphate buffer. The composition of the synthetic wastewater was as follows: starch $\left(200 \mathrm{mg} \mathrm{L}^{-1}\right)$, Bactopeptone $\left(21 \mathrm{mg} \mathrm{L} \mathrm{L}^{-1}\right)$, Bactoyeast extract $\left(100 \mathrm{mg} \mathrm{L}^{-1}\right)$, Tween-20 $\left(20 \mathrm{mg} \mathrm{L}^{-1}\right)$, urea $\left(13 \mathrm{mg} \mathrm{L}^{-1}\right)$, $\mathrm{KH}_{2} \mathrm{PO}_{4} \quad\left(5.3 \mathrm{mg} \mathrm{L} \mathrm{L}^{-1}\right), \quad \mathrm{CaCl}_{2} \cdot 2 \mathrm{H}_{2} \mathrm{O} \quad\left(22 \mathrm{mg} \mathrm{L} \mathrm{L}^{-1}\right)$, $\mathrm{MgSO}_{4} \cdot 7 \mathrm{H}_{2} \mathrm{O}\left(0.43 \mathrm{mg} \mathrm{L}^{-1}\right), \mathrm{KCl}\left(21 \mathrm{mg} \mathrm{L}^{-1}\right), \mathrm{NaHCO}_{3}$ $\left(8.8 \mathrm{mg} \mathrm{L}^{-1}\right)$ and $1 \mathrm{~mL} \mathrm{~L}^{-1}$ of a trace-element solution [Deutsche Sammlung von Mikroorganismen und

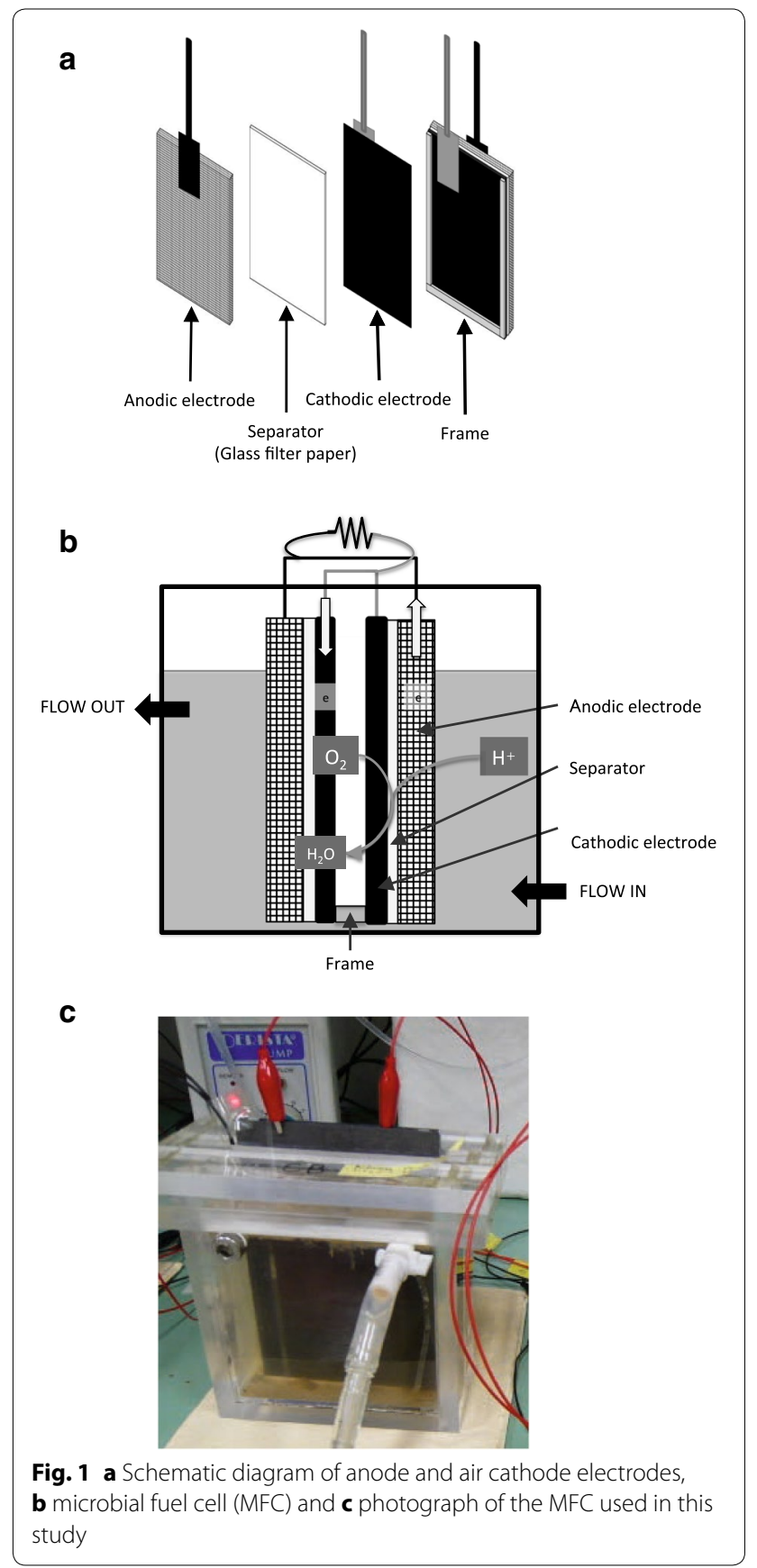

Zellkulturen (DSMZ) medium 318; Braunschweig, Germany]. The MFCs were filled with either $\mathrm{pH}$ 7.0, 5.5, or 4.0 synthetic wastewater and duplicate experiments were conducted under each condition. MFC operation was initiated by inoculating with $20 \mathrm{~mL}$ activated sludge obtained from a sewage treatment plant operated by the Tokyo Metropolitan Government. The synthetic wastewater was provided at a flow rate of $250 \mathrm{~mL}^{\text {day }}{ }^{-1}$ (hydraulic-retention time of $24 \mathrm{~h}$ ) at an initial external resistance $\left(R_{\text {ext }}\right)$ setting of $10 \mathrm{k} \Omega$. Voltage $(\mathrm{V})$ produced 
by the MFC was monitored and recorded using a data logger (NR-1000; Keyence, Osaka, Japan), and current (I) and power $(\mathrm{P})$ were calculated from the voltage at the set $R_{\text {ext }}$ using the equations $\mathrm{I}=\mathrm{V} / R_{\text {ext }}$ and $\mathrm{P}=\mathrm{IV}$, respectively. The $R_{\text {ext }}$ was dropped stepwise to $51 \Omega$ as the voltage increased in the MFC operated at $\mathrm{pH}$ 7.0.

\section{Analysis of performances of the MFC}

Chemical oxygen demand (COD) was measured with a COD reactor (DRB200, Hach, Loveland, CO, USA) using the dichromate method and COD removal efficiency (\%) was calculated from [COD concentration in synthetic wastewater $\left(\mathrm{mg}^{-} \mathrm{COD} \mathrm{L} \mathrm{L}^{-1}\right)$-COD concentration in broth $\left(\mathrm{mg}^{\left.\left.-C O D ~ \mathrm{~L}^{-1}\right)\right] / C O D}\right.$ concentration in synthetic wastewater $\left(\mathrm{mg}^{-C O D ~ L^{-1}}\right) \times 100(\%)$. The average value of the total COD concentration in synthetic wastewater was $649 \pm 44.7 \mathrm{mg} \mathrm{L}^{-1}$ (mean \pm standard deviation). The COD removal efficiency was measured in the MFC $\mathrm{pH} 7.0,5.5$, and 4.0 fermentation broths throughout the operation. The concentrations of organic acids were determined using a high-performance liquid chromatograph system (Shimadzu, Kyoto, Japan) equipped with a refractive index detector (RID-10A, Shimadzu) and an organic acid analysis column (Aminex HPX-87H; Bio-Rad, Tokyo, Japan). Coulombic efficiency (C.E.) was calculated based on the COD removal (CODin-CODout) and the measured current using the values $1 \mathrm{~g}$ of $\mathrm{COD}=0.125 \mathrm{~mol}$ of electrons and $1 \mathrm{~A}=5.39 \times 10^{23}$ electrons per day (Logan et al. 2006). Polarization and power density curves were plotted using a potentiostat (HA-1510; Hokuto Denko, Tokyo, Japan) (Shimoyama et al. 2008). Maximum power densities $\left[P_{\max }\left(\mathrm{mW} \mathrm{m}^{-2}\right)\right.$, peaks in the power density curves] and the short-circuit current density $\left.U_{s c}\left(\mathrm{~mA} \mathrm{~m}^{-2}\right)\right]$ were determined from these curves (Kato et al. 2010).

\section{Quantitative-PCR for Geobacter spp.}

A DNA sample was extracted from the surface of the anode graphite felt piece $(1 \times 2 \mathrm{~cm})$ after MFC operation using an ISOPLANT II kit (NIPPON GENE, Tokyo, Japan) according to the manufacturer's instructions. Quantitative PCR assays were performed using a realtime PCR system (StepOnePlus; Applied Biosystems, Foster City, CA, USA) and SYBR Green Real-Time PCR Master Mix kit (Applied Biosystems), as reported previously (Kato et al. 2010). The abundances of total bacteria and family Geobacteraceae were separately quantified with the primer sets B1055F (5'-ATG GYT GTC GTC AGCT-3') and B1392R (5'-ACG GGC GGT GTG TAC $-3^{\prime}$ ) (Ritalahti et al. 2006), and Geo494F (5'-AGG AAG CAC CGG CTAACT CC-3') and Geo825R (5'-TAC CCG CRA CAC CTA GT-3') (Kato et al. 2010), respectively. Standard curves were generated using serially diluted genomic DNA from G. sulfurreducens $\left(0.01-1 \mathrm{ng} \mu \mathrm{L}^{-1}\right)$. At least two separate trials were conducted on each DNA sample.

\section{Clone library analysis}

PCR amplification was performed using AmpliTaqGold (Applied Biosystems). The primer sets used were Ba27f (Escherichia coli positions 8-27) and Ba907r (E. coli positions 907-926) for the domain Bacteria (Lueders and Friedrich 2002). The PCR protocol entailed an initial denaturation for $10 \mathrm{~min}$ at $94{ }^{\circ} \mathrm{C}$; 25 cycles of denaturation for $45 \mathrm{~s}$ at $94{ }^{\circ} \mathrm{C}$, annealing for $30 \mathrm{~s}$ at $52{ }^{\circ} \mathrm{C}$, and elongation for $90 \mathrm{~s}$ at $72{ }^{\circ} \mathrm{C}$, followed by a final 5-min elongation at $72{ }^{\circ} \mathrm{C}$. The PCR amplification products were purified using a QIAquick PCR purification kit (QIAGEN, Hilden, Germany), following which the ligated PCR products were transformed into E. coli JM109 by using a pGEM-T Easy Vector System (Promega, Fitchburg, WI, USA). The plasmids were extracted from the cloned cells and purified using a GenElute plasmid Miniprep Kit (Sigma-Aldrich, St. Louis, MO, USA), after which sequencing reactions were carried out with a BigDye Terminator v 3.1 Cycler Sequencing Kit (Applied Biosystems). Nucleotide sequencing was performed with an Applied Biosystems 3130xl Genetic Analyzer (Applied

Table 1 Biochemical and electrochemical performance during stable operation of microbial fuel cells (MFCs) operating

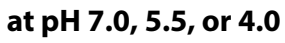

\begin{tabular}{|c|c|c|c|c|c|}
\hline MFC & COD removal efficiency ${ }^{a}(\%)$ & Total concentration of organic acids ${ }^{\mathbf{b}}(\mathrm{mM})$ & $J_{s c}^{c}\left(m_{A ~ m}{ }^{-2}\right)$ & $P_{\max }^{\mathrm{d}}\left(\mathrm{mW} \mathrm{m}^{-2}\right)$ & C.E. ${ }^{\mathrm{e}}(\%)$ \\
\hline $\mathrm{pH} 7.0$ & $57.8 \pm 8.82$ & 0.47 & $410 \pm 176$ & $381 \pm 155$ & $34.0 \pm 9.18$ \\
\hline $\mathrm{pH} 5.5$ & $57.1 \pm 12.8$ & 1.19 & $253 \pm 52.1$ & $147 \pm 18.3$ & $12.1 \pm 3.11$ \\
\hline $\mathrm{pH} 4.0$ & $56.9 \pm 3.61$ & 1.80 & $40.7 \pm 14.6$ & $5.14 \pm 1.64$ & $1.06 \pm 1.43$ \\
\hline
\end{tabular}

${ }^{a}$ Chemical oxygen demand (COD) removal efficiency (\%) was calculated as follows: $100 \times$ [COD concentration in synthetic wastewater (mg-COD $\mathrm{L}^{-1}$ )-COD concentration in broth $\left.\left(\mathrm{mg}^{-\mathrm{COD} \mathrm{L}} \mathrm{L}^{-1}\right)\right] / \mathrm{COD}$ concentration in synthetic wastewater $\left(\mathrm{mg}^{-\mathrm{COD} \mathrm{L}} \mathrm{L}^{-1}\right)$

b Sum of the organic acid concentrations in the suspended fractions of samples collected after 30 days' operation at $\mathrm{pH} 7.0, \mathrm{pH} 5.5, \mathrm{or} \mathrm{pH} 4.0$

c Short-circuit current density $\left[J_{s c}\left(\mathrm{~mA} \mathrm{~m}^{-2}\right)\right]$ was determined from the power density curves

d Maximum power density $\left[P_{\max }\left(\mathrm{mW} \mathrm{m}^{-2}\right)\right]$ was obtained from the peak in the power density curves

e Coulombic efficiency (C.E.) was calculated based on the COD removal (CODin-CODout) and the measured current, using $1 \mathrm{~g}$ of COD $=0.125 \mathrm{~mol}$ of electrons, and 1 $\mathrm{A}=5.39 \times 10^{23}$ electrons per day 
Table 2 Organic acid concentrations in the liquid fractions of MFCs operated for 30 days at pH 7.0, pH 5.5, or pH 4.0

\begin{tabular}{llllll}
\hline MFC & \multicolumn{6}{l}{ Organic acid concentration (mM) } \\
\cline { 2 - 6 } & Formate & Acetate & Propionate & Butyrate & Lactate \\
\hline $\mathrm{pH} \mathrm{7.0}$ & $\mathrm{ND}$ & 0.39 & $\mathrm{ND}$ & 0.08 & $\mathrm{ND}$ \\
$\mathrm{pH} 5.5$ & 0.27 & 0.44 & 0.19 & 0.30 & $\mathrm{ND}$ \\
$\mathrm{pH} 4.0$ & 0.18 & 0.62 & 0.47 & 0.47 & 0.06 \\
\hline
\end{tabular}

ND not detected
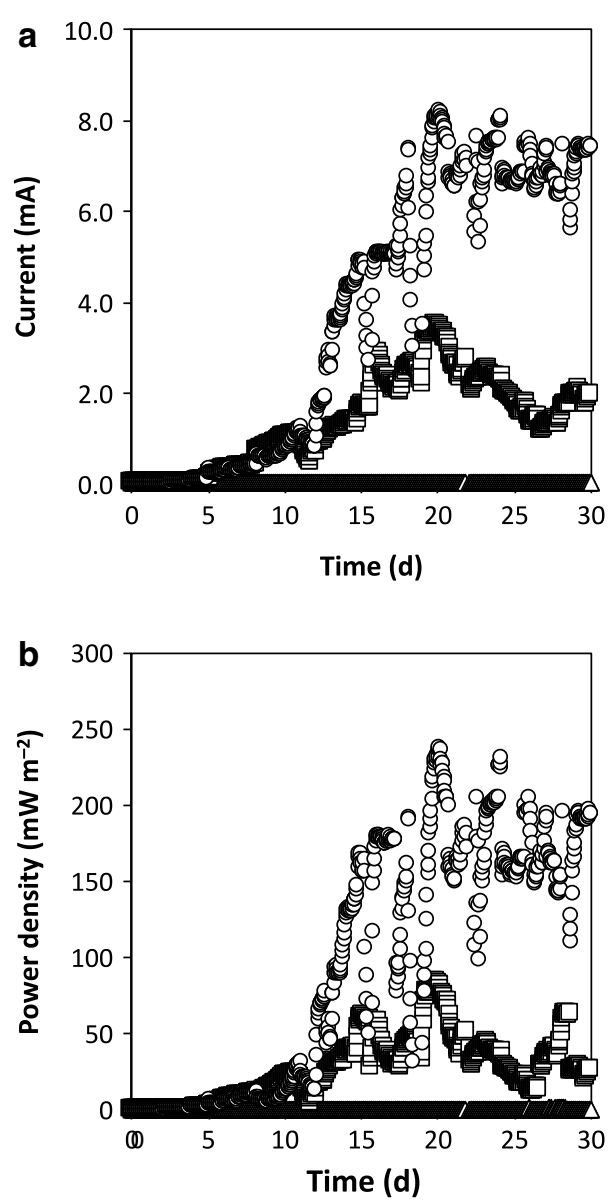

Fig. 2 Average values of $\mathbf{a}$ current ( $\mathrm{mA}$ ) and $\mathbf{b}$ power density $\left(\mathrm{mW} \mathrm{m}^{-2}\right)$ were analyzed throughout the operation period $(\mathrm{pH}$ 7.0: open circles, pH 5.5: open squares, and pH 4.0: open triangles)

Biosystems). All sequences were checked for chimeric artifacts using the Bellerophon algorithm (http://compbio.anu.edu.au/bellerophon/bellerophon.pl). Sequences with $\geq 97.0 \%$ similarity were grouped into operational taxonomic units (OTUs). Nucleotide sequences were compared to the DDBJ/EMBL/GenBank databases using the BLAST algorithm (http://www.ncbi.nlm.nih.gov/ blast/Blast.cgi). The nucleotide sequence data obtained in this study have been deposited in the DDBJ/EMBL/GenBank nucleotide sequence databases under the accession numbers LC168126 to LC168150.

\section{Metabolite extraction and quenching}

Cells were collected from the anode graphite felt after 30 days' operation at $\mathrm{pH} 7.0$ or 4.0. The cell weight in each sample was adjusted to the same level based on optical density at $600 \mathrm{~nm}\left(\mathrm{OD}_{600}\right)$ before filtering each sample through a polytetrafluoroethylene membrane filter (Omnipore, $0.45 \mu \mathrm{M}, 47-\mathrm{mm}$ diameter; Millipore, Danvers, MA, USA). The dry cell weight of each sample was estimated by multiplying the determined cell weight of E. coli by the $\mathrm{OD}_{600}$ using the equation: dry cell weight $(\mathrm{mg})=0.0582 \times \mathrm{OD}_{600} \times$ volume $(\mathrm{mL})$. Immediately after filtration, the cells were washed in place with cold phosphate-buffered saline $(137 \mathrm{mM} \mathrm{NaCl}, 8.10 \mathrm{mM}$ $\mathrm{Na}_{2} \mathrm{HPO}_{4}, 2.68 \mathrm{mM} \mathrm{KCl}$, and $\left.1.47 \mathrm{mM} \mathrm{KH_{2 }} \mathrm{PO}_{4}\right)$. The membrane filters with the washed cells were transferred to $50-\mathrm{mL}$ centrifuge tubes and then frozen in liquid nitrogen. Metabolites were extracted from the cells using a modified cold chloroform-methanol method (Putri et al. 2013). Finally, the water phase of the extract $(700 \mu \mathrm{L})$ was dried under vacuum and stored at $-80{ }^{\circ} \mathrm{C}$ until use for mass analyses (Bennett et al. 2008).

\section{GC-Q-MS and LC-QqQ-MS analyses}

The dried extract samples were thawed on ice, derivatized at $30{ }^{\circ} \mathrm{C}$ for $90 \mathrm{~min}$ with $100 \mu \mathrm{L}$ of $20 \mathrm{mg} \mathrm{mL}^{-1}$ methoxyamine hydrochloride in pyridine, then $50 \mu \mathrm{L} \mathrm{N}$-methyl- $N$ (trimethylsilyl) trifluoroacetamide (GL Sciences, Tokyo, Japan) (Lisec et al. 2006) was added followed by incubation at $37^{\circ} \mathrm{C}$ for $30 \mathrm{~min}$. Samples $(1 \mu \mathrm{L})$ of the derivatives were subjected to gas chromatography-quadrupole-mass spectrometry (GC-Q-MS) analysis (GCMSQP-2010 system, Shimadzu) for detection of metabolites from the TCA cycle, as well as the detection of glutamate and glucose.

Aliquots of the dried extract samples were also dissolved in $50 \mu \mathrm{L}$ Milli-Q water and prepared for analysis by liquid chromatography triple-stage quadrupole mass spectrometry (LC-QqQ-MS) (high-performance liquid chromatography: Agilent 1200 series, MS: Agilent 6460 with Jet Stream Technology, Agilent Technologies, Waldbronn, Germany) controlled by MassHunter Workstation Data Acquisition software (v. B. 04.01; Agilent Technologies). Metabolites from the EM and pentose phosphate (PP) pathways were detected, as well as of acetyl-CoA, adenosine triphosphate (ATP), adenosine diphosphate (ADP), nicotinamide adenine dinucleotide $\left(\mathrm{NADH}, \mathrm{NAD}^{+}\right)$, and nicotinamide adenine dinucleotide phosphate (NADPH, $\mathrm{NADP}^{+}$) (Luo et al. 2007). Details of the GC-Q-MS and LC-QqQ-MS operating conditions and methods have been described previously (Kato et al. 2012). 
Table 3 Quantitative PCR analysis of Geobacteraceae bacteria on the anodic electrode in MFCs at pH 7.0, pH 5.5, or pH 4.0

\begin{tabular}{lll}
\hline MFC & $\begin{array}{l}\text { Geobacteraceae bacteria } \\
\left(\mathbf{n g ~ c m}^{-\mathbf{2}} \mathbf{~}^{\mathbf{a}}\right.\end{array}$ & $\begin{array}{l}\text { Ratio of } \\
\text { Geobacteraceae (\%) }\end{array}$ \\
\hline $\mathrm{pH} \mathrm{7.0}$ & $965 \pm 7.50$ & $26.7 \pm 2.72$ \\
$\mathrm{pH} \mathrm{5.5}$ & $34.6 \pm 11.1$ & $1.57 \pm 0.51$ \\
$\mathrm{pH} \mathrm{4.0}$ & $0.12 \pm 0.02$ & $0.10 \pm 0.02$ \\
\hline
\end{tabular}

a The amount of DNA mass (ng) per anode graphite felt sample $\left(\mathrm{cm}^{-2}\right)$

\section{Results}

Performance and electricity generation of the MFCs The physicochemical performances of the MFCs at $\mathrm{pH}$ 7.0, 5.5, and 4.0 were compared (Tables 1, 2; Fig. 2). Similar amounts of COD were degraded by the total microflora in each MFC (Table 1). However, the total concentration of organic acids was higher at day 30 in the MFCs operated at $\mathrm{pH} 5.5$ and 4.0 compared to at $\mathrm{pH} 7.0$, and the concentration of each organic acid measured was

Table 4 Phylogenetic affiliations and number of bacterial clones obtained from retained and suspended fractions in the MFC operated for $\mathbf{3 0}$ days at pH 7.0

\begin{tabular}{|c|c|c|c|c|c|c|}
\hline \multirow[t]{2}{*}{ OTU $^{a}$} & \multicolumn{2}{|c|}{ No. of clones ${ }^{b}$} & \multirow[t]{2}{*}{ Phylogenetic group } & \multirow{2}{*}{$\begin{array}{l}\text { The closest isolated } \\
\text { strain (accession no., } \\
\text { similarity) }\end{array}$} & \multirow{2}{*}{$\begin{array}{l}\text { The closest environmen- } \\
\text { tal clone (accession no., } \\
\text { similarity) }\end{array}$} & \multirow{2}{*}{$\begin{array}{l}\text { Isolated source of envi- } \\
\text { ronmental clones }\end{array}$} \\
\hline & Retained & Suspended & & & & \\
\hline 1 & 6 & & $\begin{array}{l}\text { Proteobacteria; Deltapro- } \\
\text { teobacteria }\end{array}$ & $\begin{array}{l}\text { Geobacter sulfurreducens } \\
\text { (NR_075009,98.6\%) }\end{array}$ & $\begin{array}{l}\text { Uncultured bacterium } \\
\text { (GQ152932, 100\%) }\end{array}$ & Mixed consortium in MFC \\
\hline 2 & 4 & & $\begin{array}{l}\text { Proteobacteria; Gammapro- } \\
\text { teobacteria }\end{array}$ & $\begin{array}{l}\text { Citrobacter freundii } \\
\text { (AB548830, 100\%) }\end{array}$ & $\begin{array}{l}\text { Uncultured organism } \\
\text { (HQ745055, 99.9\%) }\end{array}$ & Gastrointestinal specimens \\
\hline 3 & 3 & 1 & $\begin{array}{l}\text { Proteobacteria; Gammapro- } \\
\text { teobacteria }\end{array}$ & $\begin{array}{l}\text { Raoultella ornithinolytica } \\
\text { (CP004142, 100\%) }\end{array}$ & $\begin{array}{l}\text { Uncultured bacterium } \\
\text { (EF515418, 100\%) }\end{array}$ & Upflow MFC anode \\
\hline 4 & 4 & 1 & $\begin{array}{l}\text { Proteobacteria; Gammapro- } \\
\text { teobacteria }\end{array}$ & $\begin{array}{l}\text { Pseudomonas fragi } \\
\text { (AB685617, 99.8\%) }\end{array}$ & $\begin{array}{l}\text { Uncultured bacterium } \\
\text { (EU469649,99.8\%) }\end{array}$ & Mammalian gut microbes \\
\hline 5 & & 5 & $\begin{array}{l}\text { Proteobacteria; Gammapro- } \\
\text { teobacteria }\end{array}$ & $\begin{array}{l}\text { Aeromonas dhakensis } \\
\text { (KF938660, 100\%) }\end{array}$ & $\begin{array}{l}\text { Uncultured bacterium } \\
\text { (JX271966, 100\%) }\end{array}$ & $\begin{array}{l}\text { Activated sludge from } \\
\text { large-scale }\end{array}$ \\
\hline 6 & & 3 & $\begin{array}{l}\text { Proteobacteria; Gammapro- } \\
\text { teobacteria }\end{array}$ & $\begin{array}{l}\text { Aeromonas sharmana } \\
\text { (NR_043470,96.9\%) }\end{array}$ & $\begin{array}{l}\text { Uncultured Aeromonas sp. } \\
\text { (EF679186, 98.6\%) }\end{array}$ & $\begin{array}{l}\text { Sewage plant } \\
\text { Anaerobic sludge from MFC }\end{array}$ \\
\hline 7 & 1 & & $\begin{array}{l}\text { Proteobacteria; Betaproteo- } \\
\text { bacteria }\end{array}$ & $\begin{array}{l}\text { Advenella kashmirensis } \\
\text { (KF956701,95.1\%) }\end{array}$ & $\begin{array}{l}\text { Uncultured bacterium } \\
\text { (FN563161, 99.7\%) }\end{array}$ & Mesophilic biogas digester \\
\hline 8 & 1 & 1 & $\begin{array}{l}\text { Proteobacteria; Betaproteo- } \\
\text { bacteria }\end{array}$ & $\begin{array}{l}\text { Azospira oryzae } \\
\text { (DQ863512, 94.1\%) }\end{array}$ & $\begin{array}{l}\text { Uncultured Azospira sp. } \\
\text { (JF736645, 96.5\%) }\end{array}$ & Biofilm on electrode in MFC \\
\hline 9 & 12 & 5 & Bacteroidetes; Cytophagia & $\begin{array}{l}\text { Pontibacter korlensis } \\
(G Q 503321,82.7 \%)\end{array}$ & $\begin{array}{l}\text { Bacteriodetes bacterium } \\
(\mathrm{JX} 828412,95.9 \%)\end{array}$ & $\begin{array}{l}\text { Iron-reducing enrichment } \\
\text { culture }\end{array}$ \\
\hline 10 & 3 & & Bacteroidetes; Bacteroidia & $\begin{array}{l}\text { Bacteroides nordii } \\
\text { (NR_112939,92.9\%) }\end{array}$ & $\begin{array}{l}\text { Uncultured bacterium } \\
\text { (KC179060,99.7\%) }\end{array}$ & Activated sludge \\
\hline 11 & & 12 & Bacteroidetes; Bacteroidia & $\begin{array}{l}\text { Dysgonomonas oryzarvi } \\
\text { (NR_113063,99.7\%) }\end{array}$ & $\begin{array}{l}\text { Uncultured Dysgonomonas } \\
\text { sp. } \\
\text { (JX535216, 100\%) }\end{array}$ & $\begin{array}{l}\text { Activated sludge from } \\
\text { sewage }\end{array}$ \\
\hline 12 & & 1 & Bacteroidetes; Bacteroidia & $\begin{array}{l}\text { Dysgonomonas capnocy- } \\
\text { tophagoides } \\
\text { (NR_113133,93.2\%) }\end{array}$ & $\begin{array}{l}\text { Uncultured bacterium } \\
\text { (HQ728219,96.1\%) }\end{array}$ & Glucose-fed MFC \\
\hline 13 & 3 & & Firmicutes; Negativicutes & $\begin{array}{l}\text { Anaeroarcus burkinensis } \\
\text { (NR_025298, 97.7\%) }\end{array}$ & $\begin{array}{l}\text { Uncultured bacterium } \\
\text { (AB329655, 99.9\%) }\end{array}$ & UASB granule \\
\hline 14 & 2 & & Firmicutes; Negativicutes & $\begin{array}{l}\text { Acidaminococcus fermen- } \\
\text { tans } \\
\text { (NR_074928,93.8\%) }\end{array}$ & $\begin{array}{l}\text { Uncultured bacterium } \\
\text { (JN680060, 99.5\%) }\end{array}$ & $\begin{array}{l}\text { Anode biofilm at psychro- } \\
\text { tolerants in MFC }\end{array}$ \\
\hline 15 & & 1 & Firmicutes; Clostridia & $\begin{array}{l}\text { Pseudoflavonifractor capil- } \\
\text { losus } \\
\text { (NR_025670,89.8\%) }\end{array}$ & $\begin{array}{l}\text { Uncultured Clostridiales } \\
\text { bacterium } \\
\text { (FJ393118,91.0\%) }\end{array}$ & Glucose-fed MFC anode \\
\hline Sum & 39 & 30 & & & & \\
\hline
\end{tabular}

\footnotetext{
a Sequences with more than $97.0 \%$ homology were considered as being the same as the operational taxonomic unit (OTU)
}

b Suspended: the suspended fraction obtained from fermentation broth, Retained: the retained fraction obtained from anode graphite felts 
higher in the MFCs operated at $\mathrm{pH} 5.5$ and 4.0 compared to at $\mathrm{pH}$ 7.0, with the concentration of acetate being the highest (Table 2). The accumulation of organic acids has often been observed in microflora cultures grown at low $\mathrm{pH}$ conditions (Sasaki et al. 2014). Differences in the environmental conditions between $\mathrm{pH} 7.0,5.5$, and 4.0 would affect the current-generating conditions in microflora on the surface of the anodic electrode.

Current production and power density in the MFC operated at $\mathrm{pH} 7.0$ began to increase at day 5 and were stable from day 20 to day 30 (Fig. 2). The electrochemical performances of the $\mathrm{pH} 7.0,5.5$, and 4.0 reactors from day 20 to day 30 are summarized in Table 1 . The values of $J_{s c}\left(410 \pm 176 \mathrm{~mA} \mathrm{~m}^{-2}\right)$ and $P_{\max }\left(381 \pm 155 \mathrm{~mW} \mathrm{~m}^{-2}\right)$ for the MFC at pH 7.0 were similar to those previously reported for MFCs (Yoshizawa et al. 2014; Zhang et al. 2015). In contrast, little current production and low power density were observed in the MFCs operated at $\mathrm{pH} 5.5$ and 4.0 throughout the operation. Accordingly, a much higher C.E. was observed in the MFC operating at $\mathrm{pH} 7.0$ (neutral $\mathrm{pH}$ ) than at $\mathrm{pH} 5.5$ and 4.0 (acidic $\mathrm{pH}$ ), in agreement with previous research by $\mathrm{He}$ et al. (2008). Because stable, middle, and low current production was verified for electrodes at $\mathrm{pH} 7.0,5.5$, and 4.0, respectively, genetic and metabolomic analyses were performed on microflora collected from the MFCs.

\section{Ratio of Geobacter species in the microflora of the MFCs}

The relationship between current production and the ratio of Geobacter to the total bacterial cells was investigated. Quantitative analysis of total bacteria and family Geobacteraceae were conducted of the microflora collected from the anodic electrodes of MFCs operated at $\mathrm{pH}$ 7.0, 5.5, and 4.0 at day 30 (Table 3). Consistent with the observed current production, the amount and the ratio of family Geobacteraceae to the total cells on the electrode at $\mathrm{pH} 7.0$ were higher than that at $\mathrm{pH} 5.5$ and 4.0, and the Geobacteraceae ratio at $\mathrm{pH} 7.0$ was similar to that reported in a previous study on electricity generation by microflora (Kouzuma et al. 2013).

Bacterial clone libraries of $16 \mathrm{~S}$ rRNA genes were constructed to further elucidate the genetic sequences of microbes belonging to family Geobacteraceae and other microbes on the anodic electrodes (Retained) and in the fermentation broths (Suspended) sampled on day 30 from MFCs operated at $\mathrm{pH} 7.0$ and 4.0 (Table 4; Additional file 1: Table S1, respectively). Sequences related to microbes belonging to family Geobacteraceae were only detected in the retained fraction of the sample obtained from the anodic electrode of the MFC operated at $\mathrm{pH} 7.0$ (Table 4). Six sequences out of a total of 39 clones in the retained fraction showed $98.6 \%$ similarity to Geobacter sulfurreducens (NR_075009).

\section{TCA cycle at $\mathrm{pH} 7.0,5.5$, and 4.0}

Synthetic wastewater containing starch as the major carbon source was continuously flowed into the MFCs and the metabolic state related to the TCA cycle of the microflora on the anodic electrode was analyzed after operating for 30 days at $\mathrm{pH} 7.0,5.5$, or 4.0 (Fig. 3). The concentration of intracellular metabolites $(\mu \mathrm{mol})$ was compared between $\mathrm{pH} 7.0,5.5$, and 4.0, based on the same cell weight (g-cell). The levels of most of the intracellular metabolites (oxaloacetate, citrate, aconitate, isocitrate, succinate, fumarate, and malate) related to the TCA cycle at $\mathrm{pH} 7.0,5.5$, and 4.0 were correlated with current densities (Fig. 3).

\section{Glycolysis (EM and PP pathways) at $\mathrm{pH}$ 7.0, 5.5, and 4.0}

The profile of intercellular metabolites related to glycolysis (EM and PP pathways) differed in the microflora samples obtained from the anodes of reactors operated at $\mathrm{pH} 7.0$, 5.5, and $\mathrm{pH} 4.0$ (Additional file 1: Figure S1). Correlations were not observed between the levels of most metabolites related to glycolysis and current density. The intracellular concentrations of acetyl-CoA were higher at $\mathrm{pH} 4.0$ and $\mathrm{pH} 5.5$ than at $\mathrm{pH} 7.0$, implying that the accumulation of organic acids at $\mathrm{pH} 4.0$ and $\mathrm{pH} 5.5$ inhibited carbon flux via acetyl-CoA (Fig. 3).

\section{Ratio of coenzymes at pH 7.0 and 4.0}

A previous study of the metabolic state of G. sulfurreducens cells showed that the ratios of intracellular coenzyme concentrations (high ATP/ADP, low NADH/ $\mathrm{NAD}^{+}$, and low NADPH/NADP ${ }^{+}$) correlated well with electricity generation (Song et al. 2016). As expected, the ATP/ADP ratio in microflora at $\mathrm{pH} 7.0$ was larger than at $\mathrm{pH} 5.5$ and 4.0 (Fig. 4). The $\mathrm{NADH} / \mathrm{NAD}^{+}$ratio at $\mathrm{pH} 7.0$ was similar to that at $\mathrm{pH} 5.5$ and was smaller than that at $\mathrm{pH} 4.0$. On the other hand, the NADPH/ $\mathrm{NADP}^{+}$ratio at $\mathrm{pH} 7.0$ was similar to that at $\mathrm{pH} 5.5$ and 4.0.

\section{Discussion}

The observed good current generation at neutral $\mathrm{pH}$ and poor current generation below pH 5.0 were in accordance with the previous study of Patil et al. (2011). In the present study, microorganisms related to Geobacter species would play a major role in current generation at the anode electrode (Lovley 2008). Geobacter cells oxidize acetate via the TCA cycle to generate electricity (Mahadevan et al. 2006). Good correlation between the levels of metabolites relating to the TCA cycle and current generation is corroborated by our previous study showing that the intracellular metabolites in the TCA cycle are present at high concentration and activation of the TCA cycle supports higher electricity generation by a 
pure Geobacter culture (Song et al. 2016). The observed decrease in Geobacter cells at lower $\mathrm{pH}$ values and current densities indicates that the metabolic state of the TCA cycle of microflora directly reflects the state of the Geobacter cells, even though the biofilm on the surface of the anode included microorganisms other than Geobacter. Thus, the present results indicate that acetate produced from starch-derived glucose through acetyl-CoA is consumed via the TCA cycle in microflora, comprised mainly of Geobacter cells, for electricity generation at $\mathrm{pH}$ 7.0 (Fig. 3).

In addition, a higher intracellular concentration of glutamate was observed at $\mathrm{pH} 7.0$ (Fig. 3). This correlates to higher cell numbers on the electrode at $\mathrm{pH} 7.0 \mathrm{com}$ pared to at pH 5.5 and 4.0 (data not shown) and supports the central importance of glutamate at the intersection between carbon and nitrogen metabolism required for bacterial growth (Commichau et al. 2008).
The profile of intercellular metabolites related to glycolysis (EM and PP pathways) at $\mathrm{pH} 7.0,5.5$, and $\mathrm{pH} 4.0$ showed no relationship with current density (Additional file 1: Figure S1). Geobacter cells reportedly down-regulate gluconeogenesis during electricity generation (Meng et al. 2013; Song et al. 2016). Because G. sulfurreducens cells cannot directly utilize glucose (Mahadevan et al. 2006), we can separate the phases of current production by microflora into an acetate-producing phase from starch via glycolysis, and a current-producing phase from acetate via the TCA cycle. Thus, intracellular metabolites related to glycolysis would be affected by carbon flux from starch-derived glucose in microorganisms other than Geobacter cells. In contrast, the intracellular concentrations of acetyl-CoA were higher at $\mathrm{pH} 5.5$ and 4.0 than at $\mathrm{pH} 7.0$, implying that the accumulation of organic acids at $\mathrm{pH} 5.5$ and 4.0 inhibited carbon flux via acetyl-CoA (Fig. 3). The same profiles were observed in

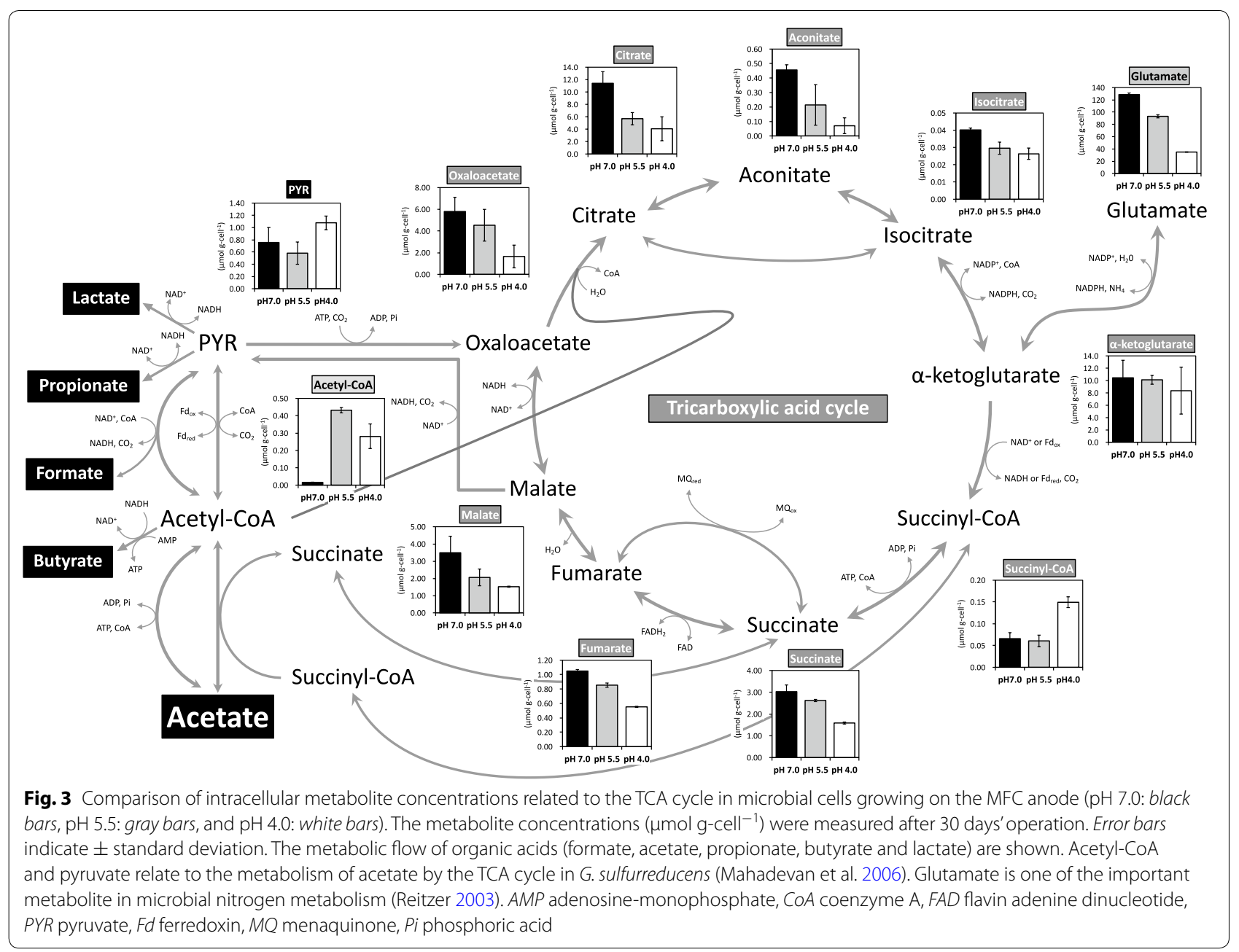



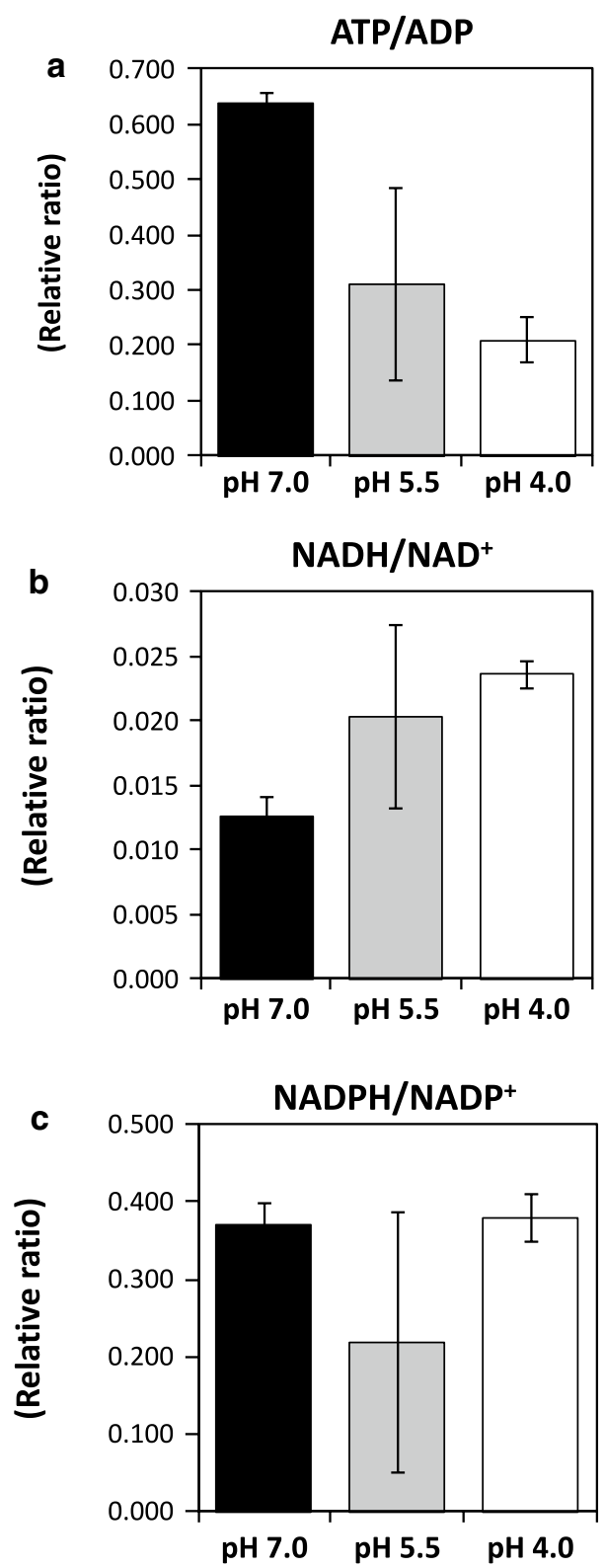

Fig. 4 The relative ratios of $\mathbf{a} A T P / A D P, \mathbf{b} N A D H / N A D^{+}$, and c NADPH/NADP ${ }^{+}$in the microbial fuel cells ( $\mathrm{pH}$ 7.0: black bars, $\mathrm{pH}$ 5.5: gray bars, and $\mathrm{pH}$ 4.0: white bars) were calculated based on the amounts of these metabolites

microflora used for methane fermentation from glucose (Sasaki et al. 2014).

ATP is produced in the respiratory electron transfer chain and oxidative consumption of NADH occurs when electricity generation is high in Geobacter species (Meng et al. 2013). ATP is also produced in the EM pathway by substrate level phosphorylation. Thus, increased ATP/ ADP would be due to activation of the EM pathway (by consumption of starch-derived glucose) and TCA cycle

(by electricity generation) at $\mathrm{pH} 7.0$ (Fig. 4). In addition, the observed decrease in the $\mathrm{NADH} / \mathrm{NAD}^{+}$ratio of the microflora at $\mathrm{pH} 7.0$ was as expected, whereas the reason for the fluctuating $\mathrm{NADH} / \mathrm{NAD}^{+}$ratio at $\mathrm{pH} 5.5$ remains unclear. In contrast, the $\mathrm{NADPH} / \mathrm{NADP}^{+}$ratio in the microflora was the same at $\mathrm{pH} 7.0,5.5$, and 4.0, although oxidative consumption of NADPH is faster in electricity-generating Geobacter cells (Song et al. 2016). During electricity generation, NADPH is produced in the TCA cycle (isocitrate to $\alpha$-ketoglutarate) and consumed during glutamate production and in the respiratory chain. In this study, NADPH was additionally supplied from the PP pathway, resulting in an increased NADPH/NADP ${ }^{+}$ratio at $\mathrm{pH} 7.0$ and 5.5.

In this study, metabolomic analyses of the microflora on the anodic electrode of a MFC showed for the first time that activation of the TCA cycle and increased ATP generation are necessary for efficient current generation from starch-like waste, as observed in single kind of microorganism, Geobacter cells.

\section{Additional file}

Additional file 1. Table S1. Phylogenetic affiliations and number of bacterial clones obtained from retained and suspended fractions in MFC operated for 30 days at pH 4.0. Figure S1. Comparison of intracellular metabolite concentrations related to central metabolism in microbial cells growing on the MFC anode at $\mathrm{pH} 7.0, \mathrm{pH} 5.5$, and $\mathrm{pH} 4.0$.

\section{Abbreviations}

MFCs: microbial fuel cells; TCA: tricarboxylic acid; ATP: adenosine triphosphate; AMP: adenosine diphosphate; EM: Embden-Meyerhof; PTFE: 4-polytetrafluoroethylene; DSMZ: Deutsche Sammlung von Mikroorganismen und Zellkulturen; $R_{\text {ext }}$ initial external resistance; COD: chemical oxygen demand; C.E.: coulombic efficiency; $P_{\max }$ : maximum power density; $J_{s c}$ short-circuit current density; DNA: deoxyribonucleic acid; PCR: polymerase chain reaction; OTUs: operational taxonomic units; $\mathrm{OD}_{600}$ : optical density at $600 \mathrm{~nm}$; GC-Q-MS: gas chromatography-quadrupole-mass spectrometry; LC-QqQ-MS: liquid chromatography triple-stage quadrupole mass spectrometry; PP: pentose phosphate; $\mathrm{NADH}$ : nicotinamide adenine dinucleotide; NADPH: nicotinamide adenine dinucleotide phosphate; 1,3 BPG: 1,3-bisphosphoglycerate; 2PG: 2-phosphoglycerate; 3PG: 3-phosphoglycerate; 6PGA: 6-phosphogluconate; 6PGL: 6-phosphogluconolactone; AMP: adenosine-monophosphate; CoA: coenzyme A; DHAP: dihydroxyacetone phosphate; E4P: erythrose-4-phosphate; F6P: fructose-6-phosphate; FAD: flavin adenine dinucleotide; FBP: fructose-1,6-bisphosphate; Fd: ferredoxin; G6P: glucose-6-phosphate; GAP: glyceraldehyde-3-phosphate; MQ: menaquinone; PEP: phosphoenolpyruvate; Pi: phosphoric acid; PPi: pyrophosphoric acid; PYR: pyruvate; R5P: ribose5-phosphate; Ru5P: ribulose-5-phosphate; S7P: sedoheptulose-7-phosphate; X5P: xylulose-5-phosphate.

\section{Authors' contributions}

DS and KS conceived the idea for this research and designed the experiments. DS performed the metabolomic analyses. DS, KS, and YT wrote the manuscript. AK designed and guided the study. All authors read and approved the final manuscript.

\section{Author details}

${ }_{1}^{1}$ Graduate School of Science, Technology and Innovation, Kobe University, 1-1 Rokkodaicho, Nada-ku, Kobe, Hyogo 657-8501, Japan. ${ }^{2}$ Institute for Frontier Science Initiative, Kanazawa University, Kakuma-machi, Kanazawa, Ishikawa 920-1192, Japan. ${ }^{3}$ Graduate School of Engineering, Kobe University, 
1-1 Rokkodai-cho, Nada-ku, Kobe, Hyogo 657-8501, Japan. ${ }^{4}$ RIKEN Center for Sustainable Resource Science, 1-7-22 Suehiro-cho, Tsurumi-ku, Yokohama, Kanagawa 230-0045, Japan.

\section{Acknowledgements}

We thank Kayano Sunada (Photocatalyst Group, Kanagawa Academy of Science and Technology) and Shuji Nakanishi (Research Center for Solar Energy Chemistry, Osaka University) for their technical support and helpful discussions. We are grateful to Yasuko Koura, Ayami Fujino and Hisae Kiriya for their analytical support.

\section{Competing interests}

The authors declare that they have no competing interests.

\section{Availability of data and materials}

The nucleotide sequence data obtained in this study have been deposited in the DDBJ/EMBL/GenBank nucleotide sequence databases under the accession numbers LC168126 to LC168150.

\section{Ethics approval}

This article does not contain any studies with human participants or animals performed by any of the authors.

\section{Funding}

We would like to acknowledge that this work was funded in part by the New Energy and Industrial Technology Development Organization (NEDO), Japan (P09010). This work was also supported by the Special Coordination Fund for Promoting Science and Technology, Creation of Innovative Centers for Advanced Interdisciplinary Research Areas (Innovative Bioproduction, Kobe) from the Ministry of Education, Culture, Sports, and Science and Technology (MEXT), Japan

Received: 25 November 2016 Accepted: 2 December 2016

Published online: 20 December 2016

\section{References}

Bennett BD, Yuan J, Kimball EH, Rabinowitz JD (2008) Absolute quantitation of intracellular metabolite concentrations by an isotope ratio-based approach. Nat Protoc 3:1299-1311. doi:10.1038/nprot.2008.107

Commichau FM, Gunka K, Landmann JJ, Stülke J (2008) Glutamate metabolism in Bacillus subtilis: gene expression and enzyme activities evolved to avoid futile cycles and to allow rapid responses to perturbations of the system. J Bacteriol 190:3557-3564. doi:10.1128/JB.00099-08

Guerrero L, Montalvo S, Coronado E, Chamy R, Poirrier P, Crutchik D, Sánchez E, De La Rubia MA, Borja R (2009) Performance evaluation of a two-phase anaerobic digestion process of synthetic domestic wastewater at ambient temperature. J Environ Sci Health A Tox Hazard Subst Environ Eng 44:673-681. doi:10.1080/10934520902847794

He Z, Huang Y, Manohar AK, Mansfeld F (2008) Effect of electrolyte pH on the rate of the anodic and cathodic reactions in an air-cathode microbial fuel cell. Bioelectrochem 74:78-82. doi:10.1016/j.bioelechem.2008.07.007

Kato S, Nakamura R, Kai F, Watanabe K, Hashimoto K (2010) Respiratory interactions of soil bacteria with (semi)conductive iron-oxide minerals. Environ Microbiol 12:3114-3123. doi:10.1111/j.1462-2920.2010.02284.x

Kato H, Izumi Y, Hasunuma T, Matsuda F, Kondo A (2012) Widely targeted metabolic profiling analysis of yeast central metabolites. J Biosci Bioeng 113:665-673. doi:10.1016/j.jbiosc.2011.12.013

Kouzuma A, Kasai T, Nakagawa G, Yamamuro A, Abe T, Watanabe K (2013) Comparative metagenomics of anode-associated microbiomes developed in rice paddy-field microbial fuel cells. PLoS ONE 8:e77443. doi:10.1371/journal.pone.0077443

Lisec J, Schauer N, Kopka J, Willmitzer L, Fernie AR (2006) Gas chromatography mass spectrometry-based metabolite profiling in plants. Nat Protoc 1:387-396. doi:10.1038/nprot.2006.59

Logan BE (2009) Exoelectrogenic bacteria that power microbial fuel cells. Nat Rev Microbiol 7:375-381. doi:10.1038/nrmicro2113
Logan BE, Hamelers B, Rozendal R, Schröder U, Keller J, Freguia S, Aelterman P, Verstraete W, Rabaey K (2006) Microbial fuel cells: methodology and technology. Environ Sci Technol 40:5181-5192. doi:10.1021/es0605016

Lovley DR (2008) The microbe electric: conversion of organic matter to electricity. Curr Opin Biotechnol 19:564-571. doi:10.1016/j.copbio.2008.10.005

Lovley DR (2012) Electromicrobiology. Annu Rev Microbiol 66:391-409. doi:10.1146/annurev-micro-092611-150104

Lueders T, Friedrich MW (2002) Effects of amendment with ferrihydrite and gypsum on the structure and activity of methanogenic populations in rice field soil. Appl Environ Microbiol 68:2484-2494. doi:10.1128/ AEM.68.5.2484-2494.2002

Luo B, Groenke K, Takors R, Wandrey C, Oldiges M (2007) Simultaneous determination of multiple intracellular metabolites in glycolysis, pentose phosphate pathway and tricarboxylic acid cycle by liquid chromatography-mass spectrometry. J Chromatogr A 1147:153-164. doi:10.1016/j. chroma.2007.02.034

Mahadevan R, Bond DR, Butler JE, Esteve-Nuñez A, Coppi MV, Palsson BO, Schilling CH, Lovley DR (2006) Characterization of metabolism in the Fe(III)-reducing organism Geobacter sulfurreducens by constraintbased modeling. Appl Environ Microbiol 72:1558-1568. doi:10.1128/ AEM.72.2.1558-1568.2006

Meng J, Xu Z, Guo J, Yue Y, Sun X (2013) Analysis of enhanced currentgenerating mechanism of Geobacter sulfurreducens strain via modeldriven metabolism simulation. PLoS ONE 8:e73907. doi:10.1371/journal. pone.0073907

Miyahara M, Hashimoto K, Watanabe K (2013) Use of cassette-electrode microbial fuel cell for wastewater treatment. J Biosci Bioeng 115:176-181. doi:10.1016/j.jbiosc.2012.09.003

Patil SA, Harnisch F, Koch C, Hübschmann T, Fetzer I, Carmona-Martínez AA, Müller S, Schröder U (2011) Electroactive mixed culture derived biofilms in microbial bioelectrochemical systems: the role of $\mathrm{pH}$ on biofilm formation, performance and composition. Bioresour Technol 102:9683-9690. doi:10.1016/j.biortech.2011.07.087

Putri SP, Nakayama Y, Matsuda F, Uchikata T, Kobayashi S, Matsubara A, Fukusaki E (2013) Current metabolomics: practical applications. J Biosci Bioeng 115:579-589. doi:10.1016/j.jbiosc.2012.12.007

Reitzer L (2003) Nitrogen assimilation and global regulation in Escherichia coli. Annu Rev Microbiol 57:155-176. doi:10.1146/annurev. micro.57.030502.090820

Ritalahti KM, Amos BK, Sung Y, Wu Q, Koenigsberg SS, Löffler FE (2006) Quantitative PCR targeting 16S rRNA and reductive dehalogenase genes simultaneously monitors multiple Dehalococcoides strains. Appl Environ Microbiol 72:2765-2774. doi:10.1128/AEM.72.4.2765-2774.2006

Sasaki D, Sasaki K, Tsuge Y, Morita M, Kondo A (2014) Comparison of metabolomic profiles of microbial communities between stable and deteriorated methanogenic processes. Bioresour Technol 172:83-90. doi:10.1016/j. biortech.2014.08.054

Shimoyama T, Komukai S, Yamazawa A, Ueno Y, Logan BE, Watanabe K (2008) Electricity generation from model organic wastewater in a cassetteelectrode microbial fuel cell. Appl Microbiol Biotechnol 80:325-330. doi:10.1007/s00253-008-1516-0

Song J, Sasaki D, Sasaki K, Kato S, Kondo A, Hashimoto K, Nakanishi S (2016) Comprehensive metabolomic analyses of anode-respiring Geobacter sulfurreducens cells: the impact of anode-respiration activity on intracellular metabolite levels. Process Biochem 51:34-38. doi:10.1016/j. procbio.2015.11.012

Toya Y, Shimizu H (2013) Flux analysis and metabolomics for systematic metabolic engineering of microorganisms. Biotechnol Adv 31:818-826. doi:10.1016/j.biotechadv.2013.05.002

Yoshizawa T, Miyahara M, Kouzuma A, Watanabe K (2014) Conversion of activated-sludge reactors to microbial fuel cells for wastewater treatment coupled to electricity generation. J Biosci Bioeng. doi:10.1016/j. jbiosc.2014.04.009

Zhang L, Zhu X, Kashima H, Li J, Ye D, Liao Q, Regan JM (2015) Bioresource technology anolyte recirculation effects in buffered and unbuffered single-chamber air-cathode microbial fuel cells. Bioresour Technol 179:26-34. doi:10.1016/j.biortech.2014.11.106 